\title{
USING CLOUD COMPUTING FOR STEM EDUCATION IN GENERAL SCHOOL
}

\author{
Nataliia Soroko \\ Ph.D. in Pedagogics, senior researcher, \\ Institute of Information Technologies and Learning Tools of NAES of Ukraine, Ukraine. \\ ORCID: 0000-0002-9189-6564, e-mail: nvsoroko@gmail.com
}

The article is devoted to the problems of using cloud services for the STEMeducation support in a general school. There is considered the foreign experience of solving the main issues on the implementation of STEM-oriented approach at all educational levels with the help of information and communication technologies. The purpose of the article is to analyze the foreign experience of using cloud computing services for the STEM-education support of a general school and highlight the main problems in this process. It is concluded that STEM-education is one of the most important areas of development education system and education reform, which is explained by the significant demand of the world labor market for specialists in the STEM industries. To ensure effective implementation of the STEM-oriented approach in the study of the general educational institution at all education levels is the use of information and communication technologies, in particular cloud services.

Key words: information and communication technologies, teacher's information and communication competence, cloud computing services, general school, STEM-oriented approach, STEM-education.

Стаття присвячена проблемам використання хмарних сервісів для підтримки STEM-освіти В загальноосвітній школі. Розглядається зарубіжний досвід Вирішення основних питань по впровадженню STЕМ-орієнтованого підходу на всіх рівнях освіти за допомогою інформачійно-комунікаційних технологій. Мета статті - проаналізувати зарубіжний досвід використання хмарних обчислювальни сервісів для підтримки загальноосвітнъої иколи $i$ виділити основні проблеми в цъому процесі. Зроблений висновок про те, що STEM-осВіта є одним з найВажливіших напряміВ розвитку осВітнъої системи $і$ реформи освіти, що пояснюється значним попитом світового ринку праці на фахівців 8 галузях STEM. Для забезпечення ефективного впровадження STEM орієнтованого підходу у навчальний процес закладу освіти на всіх освітніх рівнях необхідне використання інформаційних і комунікаційних технологій, зокрема хмарних сервісів.

Ключові слова: інформачійні $і$ комунікачійні технологї̈, компетентність викладачів і комунікацій, хмарні обчислювальні сервіси, загальноосвітня школа, орієнтована на STEM підхід, STEM-осВіта. 


\section{Introduction}

The rapid development of the information society contributes significantly to the deepening of scientific research and the emergence of new fields of knowledge and technologies, such as information and communication technologies (ICTs), nanotechnologies, biotechnologies, etc. This leads to changes in the priorities in the field of education [3].

The focus of the educational process of the general educational institution is the orientation of teachers towards a competent approach, the development of students' sense of initiative and entrepreneurship, creative thinking, the ability to transform ideas into life through creativity, innovation, etc.

The one of the main trends of education modernization is the focus on the STEM-education, which involves the integration between the disciplines of the natural sciences, the technological sciences, engineering, and mathematics, in the educational process of the education institution, in particular, the Ministry of Education and Science.

In addition to the above, there is a problem with the selection of the necessary forms, methods and means for the effective organization of this education. One of the global trends to ensure this process is the use of ICTs, in particular cloud services, reflected in such international instruments of strategic importance as the European Union's International Project «Assessment and Learning in the $21^{\text {st }}$ Century Skills» (ATC21S) [2],UNESCO ICT Competency Framework for Teachers [12], «DigComp 2.0: The Digital Competence Framework for Citizens» [13], «DigComp 2.1: The Digital Competence Framework for Citizens with eight proficiency levels and examples of use»[4], etc.

This research aims to answer the following questions:

- What problems are when using cloud technologies for the organization STEM-education?

- Which are cloud services for STEM-education?

- How to solve the problem using cloud technologies for the STEM-education support in a general school?

Problems of the development STEM-education in a general school are being considered by scientists Barna, O. and Balyk, N. (2017), Maïté Debry and Dr. Agueda Gras-Velazquez (2016), Vimala Judy Kamalodeen etc. (2017), Heidi Sublette (2013), Nikirk, M. (2012),etc

Questions of the use ICT, in particular cloud services, to improve the organization of the educational process in the general school are considered in the researches of scientists Bykov, V. (2008), Carretero, S. (2017), Vuorikari, R. (2016), Koutsopoulos, K. (2015), etc.

Researchers Barna, O., Balyk, N. suggest to consider «STEM-education» as a pedagogical approach in education, which involves the study of science and technology through the use of technical creativity and engineering, based on which mathematical calculations and modeling, as well as integrated use of various tools and tools of other sciences [2]. 
Nikirk, M. (2012) [9] provides such a definition: STEM-education is a transdisciplinary teaching approach that enables students to use the project method to independently solve real problems that may arise in bit and teaching tasks set by the teacher, in which the teacher carries out the role of facilitator. Researcher recommends such strategies for the effective implementation of the STEM-oriented approach in the generalschool:

- demonstrate graphs at the beginning of students' tasks, etc., since visualization facilitates faster perception of the material than read the text;

- begin with an explanation of the purpose, which should be based on objectivity;

- after explaining the goal it is necessary to provide students with concrete and abstract concepts to be realized using examples from real life so that students can understand the connection with abstract concepts;

- use ICTs to provide interactive educational process, namely, to search for and present educational resources; creation and application of virtual laboratories, electronic educational games, software, blogs, etc.;

- teach of the behavior and business etiquette that meets the needs of business and entrepreneurship; presentation of data using charts and graphs using graphical editors and presentations; approach;

- focus not on the teacher-centered approach, but on the learner-centered

- focus not on the teacher group-work, but on the team-work;

- promote the development an educational environment, in which the core values are students creative and independent thinking;

- engage students through interactive curriculum; teach them to evaluate and efficient to use the technology, including ICTs, for learning and self-education;

- use method «peer-to-peer», that is to engage students as teachers, project leader, problem solvers, problem solvers, this should promote them leadership skills.

The above recommendations point to the ICTs' special role, in particular, cloud services, for the STEM-education support in the general school.

An important is to create ICTs' centers support for the STEM-education, STEM Alliance, or Association, etc. For examples: The All-Ukrainian Scientific and Methodological Virtual STEM Center of the Minor Academy of Sciences of Ukraine (available at: http://stemua.science); European Union STEM Alliance in Genious Education and industry (available at: http://www.stemalliance.eu); American National School Boards Association (available at: https://www.nsba.org), etc.

STEM-educational environment of the All-Ukrainian Scientific and Methodological Virtual STEM Center consists with three components:

$\checkmark$ Information and technological component (educational programs, methodical materials, virtual laboratories);

$\checkmark$ Dimensional and material component (equipments and software for leading local and foreign producers);

$\checkmark$ Social and personal component (students of general schools and out-ofschool educational institutions, students of higher educational institutions, scientists and researchers, etc.). 
Environment of the European Union STEM Alliance has a similar structure to the All-Ukrainian Scientific and Methodological Virtual STEM Center.

Maïté Debry and Dr. Agueda Gras-Velazquez, etc. [7] consider that STEM Alliance should be special attention to cloud services for the STEM-education support. They note that use ICTs will to enable students in active, interactive and collaborative learning; increase their interest and motivation to study STEM disciplines. Scientists are separate, among cloud services, which provide interactive and collaborative learning activities for students and teachers: Microsoft Office 365, Google Docs, Microsoft OneDrive, Padlet, Skype, etc.

In this case, they see such problems [7]: creating formal and informal on-line courses in areas of STEM, and engaging students, teachers and specialists to this courses; continuous development of teacher's information and communication competence (digital competence) for their promotion of the STEM-education learning environment through the using ICTs; selection necessary ICTs for the educational process organization, etc. They propose conducting teaching courses for teachers to solve these problems, the goals of which are to teach them to select and use ICTs, in particular cloud services, in accordance with the forms, methods of teaching and the content of the teaching they teach. Scientists point out the following popular courses in EU countries: «Teach Scape» and Knowledge Delivery System (KDS); Massive open online courses (MOOC), such as, for example, European Schoolnet Academy (available at: http://www.europeanschoolnetacademy.eu); Microsoft Imagine Academy (available at: https://member.imagineacademy.microsoft.com (English); (http://kubg.edu.ua/struktura/pidrozdili/ndl-informatizatsiji-osviti/proekty/mi crosoft-imagine-academy.html (Ukrainian)), etc.

Scientists especially note the role MOOC for the development of teachers' digital competence, which aim is development them skills to use ICTs in professional activity according to global priorities of education. For example, European Schoolnet Academy courses «Boosting a Sense of Initiative and Entrepreneurship in Your Students»; «Opening minds to STEM careers», «Opening Schools to STEM Careers», etc. Scientists explain the effectiveness of such courses because of the fact that they involve a large number of teachers from different countries, which impacts exchange of positive experiences on the use of ICTs between them, to find out common problems in education that require discussion and decision, etc. [10].Teachers research different ideas about the forms, methods and means of the STEM-oriented approach support in such courses.

These courses are usually the result of international projects aimed at solving current educational problems and meeting the needs of the information society. For example, course «Opening Schools to STEM Careers» is the result of three projects: SYSTEMIC (available at: http://www.ngofund.org.pl/systemic-projects), which was a joint initiative of Ministries of Education in Europe and employers, who have a common goal - increasing the interest of young people in STEM careers; Scientix (available at: http:/ / www.scientix.eu), which provided for the creation of a community of teachers and specialists for the support and development of STEM education in Europe and the cooperation of teachers, researchers, political and other professionnals; STEM Alliance (available at: http://www.stemalliance.eu), the purpose of 
which was to identify shortcomings in the development of Science and Mathematics Education in Europe and provide suggestions for its improvement [6].

In addition to the above, scientists are call attention to the potential of cloud services for the creation and use of games in order to increase the students motivation to study and improve the educational process of disciplines STEMeducation, such as Scratch (available at: http://scratch.mit.edu), Microsoft Kodu (available at: www.kodugamelab.com), Minecraft (available at: https://minecraft. net/en-us/download), World of Warcraft (available at: https://worldofwar craft.com), etc. $[12 ; 7 ; 6]$. In order to explain the role of such services in the educational process of the general school and the training of teachers to use them in their professional activities within the European Schoolnet Academy, three rounds of the mass open online course were developed: «Games in Schools first round», «Games in Schools $2^{\text {nd }}$ round», "Games in Schools $3^{\text {rd }}$ round».

The main issues that are considered and addressed in these courses are: «Why Use Computer Games at Schools?»; «How to use cloud services to increase students motivation to study and improve the educational process of different disciplines?», etc. So, in the course «Opening Schools to STEM Careers» offered a range of computer games and cloud services to create them. Tutors of the course are conditionally divided into the following:

- which do not necessarily have an educational purpose, but can actually be used for thematic training on such issues as, for example, programming, gravity, planet, construction, and many others;

- which have a clear pedagogical orientation and designed to help students study in various fields of science for cross-curriculum learning.

At the same time, researchers are call special attention to cloud service Scratch, which was created in Media Laboratory at the Massachusetts Institute of Technology (MIT) [6]. The work on this project focused on helping students develop critical, creative thinking, individual and cooperative learning and teaching work in the classroom, encouraging joint educational activities, an interdisciplinary approach to the learning process with ICT, and others [6]. The service Scratch can be used for the following purposes: teaching and learning students for programming, algebra and geometry problems solving by students, presentation of the educational projects results of different educational disciplines, creative solution for submitting materials as a result of scientific research, and others.

Regarding issues and problems of the cloud services using for the STEMeducation support have facilitated the establishment of a number of international projects, for example: The Global Learning and Observations to Benefit the Environment (GLOBE, available at: https://www.globe.gov), Group-Based Cloud Computing for STEM Education Project (GbCC, available at: https://www.gbccstem. com), School on the Cloud (available at: http:/ / www.schoolonthecloud.net), etc.

The GLOBE (started in 1995) is an international science and education program that provides students, teachers and scientists all over the world with the opportunity to participate in data collection and scientific, educational process of Science and Mathematics Education, to promote understanding of the Earth's system and the global environment. The cloud for this project (created in 2012) is 
Infrastructure, which provides the exchange of data between its registered participants, joint work on scientific research, which are offered by educational institutions of different countries, etc.

The GLOBE Program Operational Structure consists of three levels (Figure 1): Primary Activities, Support Infrastructure and Underpinning Operations).

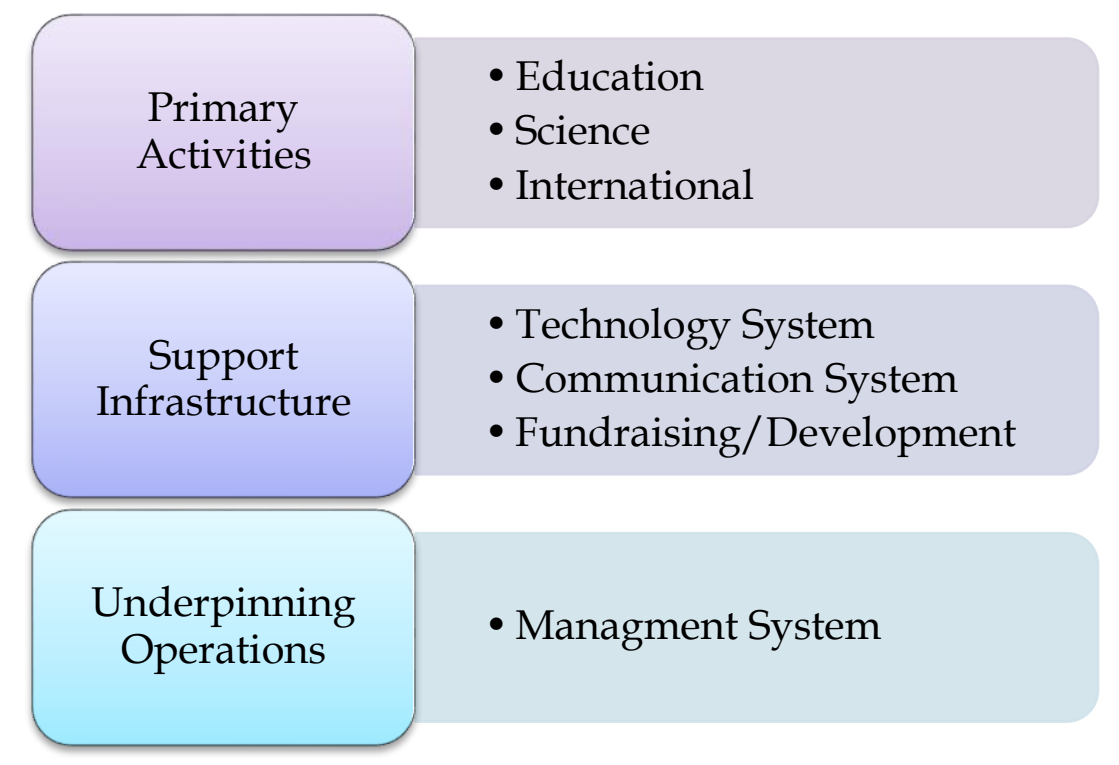

Figure 1. The GLOBE Program Operational Structure [11]

Primary Activities includes such components:

- Education: development and support of events for teachers and trainers in the environmental sciences field; communication with teachers, exchange of best practices and provision of tools; facilitating the students learning, students cooperation with the community GLOBE.

- Science: engaging scientists, which are professionals in areas of STEM, to the network of the project community GLOBE; coordination of scientific activity and educational relations; organization of communication of project participants with scientists, sharing best practices and providing feedback to schools.

- International: engaging and supporting international partners, sharing best practices among international coordinators and partners, creating conditions for education and teacher training, which are involved with the project GLOBE.

Support Infrastructure includes such components:

- Technology Systems: Websites development for GLOBE, providing cloudbased training support, data visualization project pupils and students GLOBE;

- Communication Systems: providing constant support for communication between schools, registered in the project, and scientists and partners; regular news reporting about projects, etc.;

- Fundraising/Development: identification of financing sources for relevant projects under GLOBE and a strategic plan for infrastructure support.

Underpinning Operations, which cover management systems, whose mission is to maximize the effectiveness of all activities in GLOBE, providing adequate 
monitoring, review, evaluation of services and ensuring their constant improvement.

Project GbCC aimed at implementing a research approach using cloud services to create and study technologies, and materials that support STEM-education and training. The GbCC sites have such goals:

- Distribution approaches to training and certification for teachers in STEMeducation;

- Monitoring results of using cloud services for the STEM-education support in the general school;

- Formation students «Computational thinking» in areas of STEM, which is understood as the processing of data with the help of ICT in order to improve their analysis and synthesize the material presented by students to the project site;

- Raising the level of students' knowledge about the STEM profession; motivate students to pursue appropriate education pathways occupations in STEM areas; development STEM skills, promote students critical thinking, etc.

It is worth noting the project «School on the Cloud» [5], funded with the support of the European Commission within the lifelong learning program. The project network will bring together 57 partners, 18 European countries, 10 schools, 21 universities, companies, non-governmental organizations, national authorities, research centers, associations and adult education providers. Within the project, cloud services are offered by companies Apple, Google, Microsoft, SAM Labs, etc.

It should be noted that in all the projects and studies described above, a special role is assigned to Cloud-based Simulations and Cloud-based Distributed Network Simulation Environment for students to carry out scientific research, in particular in areas of STEM. For examples, Google Maps, NetLogo, HubNet, etc.

According to the reviewed projects and studies, we can distinguish the main problems with using ICTs, in particular, cloud services, for the STEM-education support in the general school, and possible solution them (Table 1).

Table 1

The main problems with using ICTs for the STEM-education support in the general school and possible solution them

\begin{tabular}{c|c}
\hline $\begin{array}{c}\text { Problems with using ICTs } \\
\text { for the STEM-education } \\
\text { support in the general } \\
\text { school }\end{array}$ & \multicolumn{1}{c}{ Possible solution problems } \\
\hline $\begin{array}{c}\text { Teachers unreadiness, } \\
\text { unwillingness, and } \\
\text { inability to use ICTs for } \\
\text { STEM-education support } \\
\text { in them classroom }\end{array}$ & $\begin{array}{l}\text { Creating courses (MOOC) for teachers using ICTs for } \\
\text { STEM-education support, and for cooperative learning } \\
\text { and teaching activity [1;9; 7; 5] }\end{array}$ \\
\hline $\begin{array}{c}\text { Development an virtual } \\
\text { STEM-education } \\
\text { environment }\end{array}$ & $\begin{array}{l}\text { Engaging students, teachers, students of general schools } \\
\text { and out-of-school educational institutions, students of } \\
\text { higher educational institutions, scientists and resear- } \\
\text { chers, etc. to development an virtual STEM-education }\end{array}$ \\
\hline
\end{tabular}




\begin{tabular}{|c|c|}
\hline $\begin{array}{l}\text { Providing policy and } \\
\text { management STEM- } \\
\text { education support }\end{array}$ & $\begin{array}{l}\text { Creating ICTs centers for STEM-education support, that } \\
\text { must be coordinate national and international projects; } \\
\text { select and offer ICTs for STEM-education support; } \\
\text { organization national and international conferences, } \\
\text { trainings, webinars, etc.; provide monitoring the quality } \\
\text { and impact to STEM-education }[7 ; 11 ; 5]\end{array}$ \\
\hline $\begin{array}{l}\text { Motivation of students to } \\
\text { study disciplines STEM- } \\
\text { education }\end{array}$ & $\begin{array}{l}\text { Promote "organizing fundraising events with the com- } \\
\text { munity or other projects that increase budgeting and } \\
\text { math skills; teaching youth at science summer camps or } \\
\text { after-school programs; getting students to join math and } \\
\text { science clubs; exploring technology hobbies among } \\
\text { school children; helping them to participate in science } \\
\text { fairs; basic computing and internet browsing; including } \\
\text { them in Internet forums and social networking; giving } \\
\text { them books and magazines on science and mathematics; } \\
\text { motivating them to pursue science and engineering } \\
\text { careers; and helping them to learn about computer } \\
\text { parts; etc.» [8]. }\end{array}$ \\
\hline
\end{tabular}

So, in light of the projects described above and the issues that are find out, cloud services help teachers to solve problems of the balance between the content of the curriculum and the practice, between the students attendance of classes and their interests, and the rapid ICTs development and their effective use in educational process, etc.

\section{Conclusions}

The STEM-education is one of the most important areas for the development and education reforming, due to the high demand of the global labor market for specialists in the STEM industries.

To ensure the effective implementation of the STEM-oriented approach to the educational process of the general school at all levels of education is the use of ICT, particular cloud services.

The main problems that arise during this process:

- Creating formal and informal STEM online courses through ICT and involving students, teachers and professionals.

- Development of teachers' information and communication competence in order to facilitate the continuous improvement of the STEM education environment through the use ICTs, in particular cloud services.

- Selection necessary ICT for the educational process organization, etc.

Solutions to these problems are:

$\checkmark$ Creation and organization of Massive open online courses for teachers providing an opportunity for anyone, who wants to acquire certain knowledge and develop their skills in ICT teaching, regardless of their qualifications, pedagogical 
experience, etc.

$\checkmark$ Schools participation in educational projects aimed at promoting the development of teachers' skills and abilities to use ICTs, in particular cloud services, in their professional activities in accordance with the world's priority areas of education.

A research perspective on the use of cloud services for the STEM-education support in a general education institution is the design of a cloud-based environment STEM-education for schools.

\section{References:}

1. Assessment and Teaching of 21st Century Skills (ATC21S) project [online]. Available at: https://www. cisco.com/c/dam/en_us/about/citizenship/socio-economic/docs/ATC21S_Exec_Summary.pdf.

2. Barna, O. V, Balyk, N.R. Vprovadzhennia STEM-osvity u navchalnykh zakladakh: etapy ta modeli STEM v osviti: problemy i perspektyvy. STEM-osvita ta shliakhy yii vprovadzhennia $v$ navchalnovykhovnyi protses, m. Ternopil, 2017, s. 3-8.

3. Bykov, V. Yu. (2008) Models of the open education organizational systems: Monograph. K.: Atika, $684 p$.

4. Carretero, S.; Vuorikari, R. and Punie, Y. (2017). DigComp 2.1: The Digital Competence Framework for Citizens with eight proficiency levels and examples of use. Publications Office of the European Union EUR 28558 EN, DOI: 10.2760/38842 [online]. Available at: http://publications.jrc.ec.europa.eu/repo sitory/bitstream/JRC106281/web-digcomp2.1pdf.

5. Koutsopoulos, K. C. (2015). School on the Cloud: Connecting for Digital Citizenship. European Commission: Lifelong Learning Program - ICT Key Action European Project. 126 p. [online]. Available at: http://www.schoolonthecloud.net/outputs04.

6. Lewis, C. M. (2010). How programming environment shapes perception, learning and goals: logo vs. scratch. In Proceedings of the 41st ACM technical symposium on Computer science education. pp. 346-350.

7. Maité Debry and Dr. Agueda Gras-Velazquez (2016). ICT Tools for STEM teaching and learning. Transformation Framework [online]. Available at: http://www.stemalliance.eu/documents/99712/104016/ STEM_A_and_MS_ICT_Tools_in_Edu_paper_v06_Final.pdf/be27b1aa-c4a6-40c5-a750-2a11b9f896b6.

8. Md. Mokter Hossain, Michael G. Robinson (2012). How to Motivate US Students to Pursue STEM (Science, Technology, Engineering and Mathematics) Careers.US-China Education Review. 442-451 pp. [online]. Available at: https://files.eric.ed.gov/fulltext/ED533548.pdf.

9. Nikirk, M. (2012). Teaching STEM to millennial students. Tech Directions 71(7), 13-15. [online]. Available at: $h$ ttp://www.omagdigital.com/publication/?i=98503.

10. Soroko, N. V. Masovi vidkryti yevropeiski on-lain kursy dlia vchyteliv. Informatsiinyi biuleten № 1, 2017. Elektronna biblioteka Natsionalnoi akademii pedahohichnykh nauk Ukrainy. Available at: http://ib. iitta.gov.ua/706093.

11. The GLOBE program. Strategic Plan 2012-2017 [online]. Available at: https://www.globe.gov/ documents/10157/7a6bbe54-cbef-42fd-b2e0-1510c943aac4.

12. UNESCO (2015). ICT Competency Standards for Teachers. Available at: http://unesdoc.unesco.org/ images/0015/001562/156207e.pdf.

13. Vuorikari, R., Punie, Y., Carretero Gomez S., Van den Brande, G. (2016). DigComp 2.0: The Digital Competence Framework for Citizens. Update Phase 1: The Conceptual Reference Model. Luxembourg Publication Office of the European Union. EUR 27948 EN. DOI: 10.2791/11517 [online]. Available at: http://publications.jrc.ec.europa.eu/repository/bitstream/JRC101254/jrc101254_digcomp\%202.0\%20the \%20digital\%20competence\%20framework\%20for\%20citizens.\%20update\%20phase\%201.pdf. 